\title{
Analysis of the robustness of a steel frame structure with composite floors subject to multiple fire scenarios
}

DOI:

$10.1177 / 1369433221992494$

\section{Document Version}

Accepted author manuscript

Link to publication record in Manchester Research Explorer

\section{Citation for published version (APA):}

Suwondo, R., Cunningham, L., Gillie, M., \& Bailey, C. (2021). Analysis of the robustness of a steel frame structure with composite floors subject to multiple fire scenarios. Advances in Structural Engineering, 1-14.

https://doi.org/10.1177/1369433221992494

\section{Published in:}

Advances in Structural Engineering

\section{Citing this paper}

Please note that where the full-text provided on Manchester Research Explorer is the Author Accepted Manuscript or Proof version this may differ from the final Published version. If citing, it is advised that you check and use the publisher's definitive version.

\section{General rights}

Copyright and moral rights for the publications made accessible in the Research Explorer are retained by the authors and/or other copyright owners and it is a condition of accessing publications that users recognise and abide by the legal requirements associated with these rights.

\section{Takedown policy}

If you believe that this document breaches copyright please refer to the University of Manchester's Takedown Procedures [http://man.ac.uk/04Y6Bo] or contact uml.scholarlycommunications@manchester.ac.uk providing relevant details, so we can investigate your claim.

\section{OPEN ACCESS}




\title{
Analysis of the Robustness of a Steel Frame Structure with Composite Floors subject to Multiple Fire Scenarios
}

\begin{abstract}
This study presents robustness analyses of a three-dimensional multi-storey composite steel structure under the action of multiple fire scenarios. The main objective of the work is to improve current understanding of the collapse resistance of this type of building under different fire situations. A finite element approach was adopted with the model being firstly validated against previous studies available in the literature. The modelling approach was then used to investigate the collapse resistance of the structure for the various fire scenarios examined. Different sizes of fire compartment are considered in this study, starting from one bay, three bays and lastly the whole ground floor as the fire compartment. The investigation allows a fundamental understanding of load redistribution paths and member interactions when local failure occurs. It is concluded that the robustness of the focussed building in a fire is considerably affected by the size of fire compartments as well as fire location. The subject building can resist progressive collapse when the fire occurs only in the one-bay compartment. On the other hand, total collapse occurs when fire is located in the edge three-bay case. This shows that more than one fire scenario needs to be taken into consideration to ensure that a structure of this type can survive from collapse in the worst-case situation.
\end{abstract}

Keywords: composite floors; dynamic analysis; fire engineering; progressive collapse; robustness

\section{Introduction}

In the traditional approach to fire design, the fire performance of a building is practically determined according to a standard fire test, which is based on the fire behaviour of an isolated single element with ideal boundary conditions and loading (BS EN, 1990). Fire safety design based on the standard fire test is generally effective to prevent collapse of the building. However, the test is very conservative and does not represent the actual in-service condition since it does not consider member interaction and boundary conditions which may influence the behaviour of the structural element as part of the entire structural system. Accordingly, the real behaviour of the entire building structure during a fire cannot be accurately predicted using the conventional approach. 
To understand the actual behaviour of multi-storey frame structures in fire conditions, full scale fire tests were conducted on an eight-storey composite steel framed building at Cardington, UK(Bailey, 2004; M. Gillie et al., 2001; Kirby, 1998). The tests indicated that the fire resistance of the composite steel frame was greater than that of a single element in the standard fire test since tensile membrane action developed within the slabs. Therefore, investigating the whole structure is necessary to understand the real behaviour during a fire event.

In accidental events such as fire, a building must have the ability to remain standing for a certain period to ensure an acceptable level of occupant safety and to limit the economic loss. The designers have a responsibility to ensure the corresponding fire safety of the building. One of the most extreme and well-known cases of this type would be the collapse of World Trade Center towers, New York in 2001. This serves as a tragic reminder of the consequences that can result from initial localised failure followed by fire. Such events demonstrate that the failure of individual elements may trigger the collapse of the entire building or a large part of it. Robustness can be defined as the ability of structures to maintain their stability under events such as fire, without disproportional failure after local damage.

To date, research on the robustness analysis of composite steel buildings subject to fire are relatively limited. Porcari et al.(2015) presented a brief overview of current work carried out by researchers into the mechanisms of progressive collapse of steel buildings subject to fire. Observations from existing work show that structures with large cross-section members commonly have a higher collapse resistance compared to ones with small members. This is because the large cross-section members have higher strength and stiffness which have a substantial effect on the fire resistance. Moreover, a large cross-sectional area can delay the onset of thermal strain effects since the heat is dissipated over the larger area.

Sun et al.(2012) developed an approach which could be described as a combined static-dynamic technique using the software Vulcan to analyse the collapse resistance of 2-D steel frames under fire conditions. This approach allows a simulation to carry on beyond temporary instabilities which can cause singularities in the conventional analysis. Thus, this same approach can be utilised to investigate the progressive collapse behaviour of a building triggered by local damage. The results of parametric studies found that the beams and columns with lower load ratios (i.e. applied load/load capacity) can improve the robustness of steel frames in a fire. Jiang et al.(2017b) investigated the influence of dynamic effects caused by buckling of columns on the progressive collapse resistance of a steel frame. The results showed that the effect of the damping ratio is negligible on the progressive collapse analysis. However, since buckling of columns can occur suddenly, high strain rates may be incurred, which in turn need consideration of such effects in the steel. Thus, disregarding dynamic effects may lead to underestimation of structural response resulting in unsafe design. 
More recent studies have developed 3D frame models to study the robustness of steel frames with composite slabs in fire situations (Agarwal \& Varma, 2014; J. Jiang \& Li, 2017a, 2017b; Suwondo et al., 2019). The results showed that 3D models predict different collapse modes and load redistribution paths compared to those of $2 \mathrm{D}$ frames. Although the $2 \mathrm{D}$ models can capture some critical issues, the load redistribution path particularly along two horizontal directions cannot be accurately predicted. Once a column fails under fire, the load will be transferred to the surrounding elements to maintain overall structural stability. The robustness of the frames is primarily influenced by unequal load redistribution which cannot be predicted in the 2D model. Jiang and $\mathrm{Li}(2017 \mathrm{a})$ showed that the $2 \mathrm{D}$ model produces more conservative collapse resistance compared to the $3 \mathrm{D}$ model. Additionally, it was found that the concrete slab has a significant role in the uniform redistribution of the axial load released by the failed column to the adjacent columns.

To date, most of the previous studies focussed on the robustness of the building under very localised fire scenarios. There remains a lack of understanding on the collapse mechanism of composite building structures subjected to multiple fire scenarios as may occur in real fire conditions. The intention of this study is to improve the understanding of structural robustness of such structures under fire conditions. Initially, a simplified 3D numerical model is proposed to simulate the progressive collapse mechanism of the composite steel frame subject to fire. Then, a series of progressive collapse analyses are conducted on the building frame under possible fire scenarios to study the effect of fire size and fire location on the robustness of the building.

\section{Subject building frame}

The analysed building frame consists of three bays and five storeys, as shown in Figure 1. The structure is a moment resisting frame and was designed for medium seismicity, according to Eurocode 3(CEN, 2005a), 4(CEN, 2005b) and 8(CEN, 2004b). The following member sizes are used:

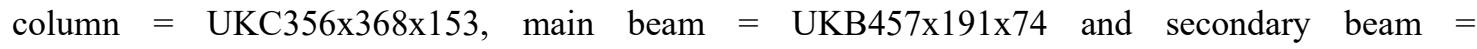
UKB356x127x39. The steel has yield strength and Young's modulus of $355 \mathrm{MPa}$ and $210 \mathrm{GPa}$, respectively. A concrete slab with a uniform thickness of $130 \mathrm{~mm}$ is adopted to study its contribution to the structural robustness of the building. The concrete slab has $6 \mathrm{~mm}$ diameter bars at $200 \mathrm{~mm}$ centres each way located at mid-depth. The compressive cylinder strength of concrete is taken as 45 $\mathrm{MPa}$, while the rebar has a yield strength of $450 \mathrm{MPa}$.

According to the previous study on the simplified UK Cardington Test(Gillie, 2009), the thermal expansion coefficients of concrete and steel material are taken as $13 \times 10^{-6}{ }^{\circ} \mathrm{C}^{-1}$ and $1.35 \times 10^{-5}{ }^{\circ} \mathrm{C}^{-1}$ 
respectively. The material properties at elevated temperature according to Eurocode 2(CEN, 2004a) and Eurocode 3(CEN, 2005a) are adopted. The total gravity load used in this study is $5.5 \mathrm{kN} / \mathrm{m}^{2}$, which is the total load at the fire limit state $(1.0 \mathrm{x}$ dead load $+0.5 \mathrm{x}$ live load $)$ calculated according to Eurocode 1(CEN, 2002). This load level produces a load ratio of 0.3 and 0.5 at the internal column and beams respectively. The columns are designed with the same section size for all storeys so that the largest load ratio is located at the ground floor.
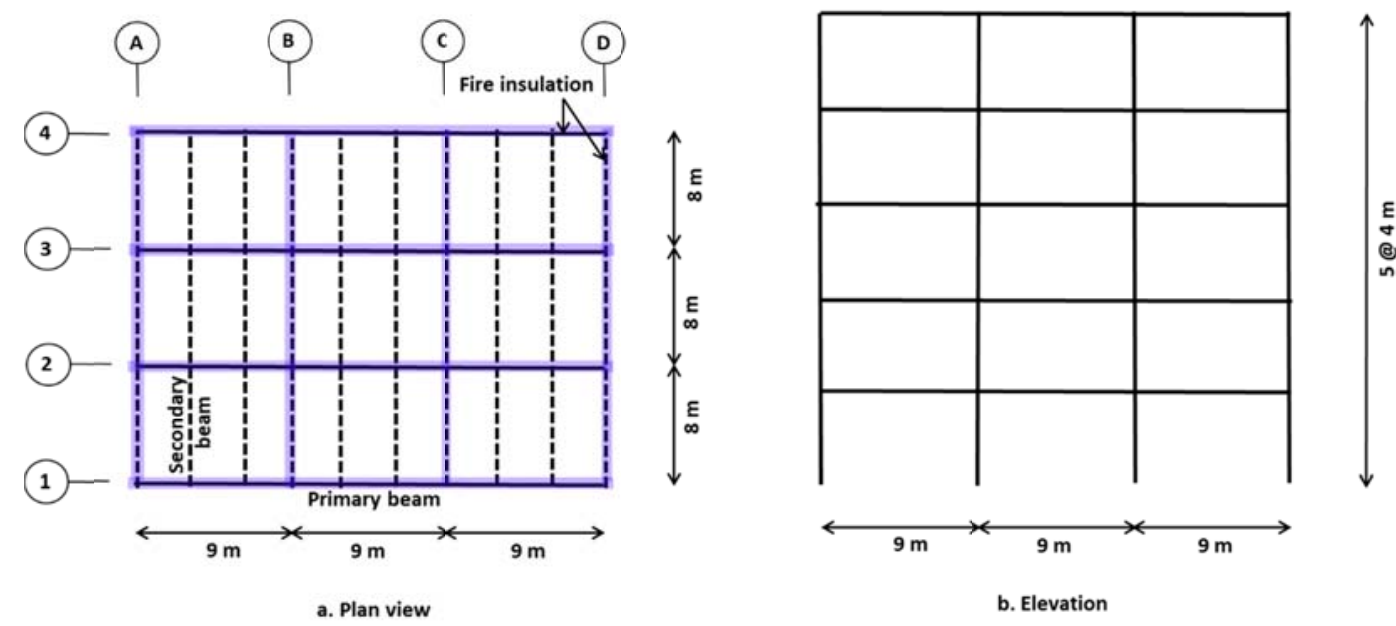

Figure 1: Subject building frame: typical floor plan and elevation

\section{Fire scenarios}

Current design methods allow the application of finite-element models to evaluate building behaviour in fire conditions. The models are subjected to a fire curve which is a temperature-time relationship and then the behaviour of the structure is observed. There are many design fire curves in the literature such as ISO 834 Standard Fire(BSI, 2014) and the EC Parametric Fire(CEN, 2005a), as shown in Figure 2. Although the Standard Fire is generally the most common method, it does not represent real fires since it is not influenced by the specific characteristics of the building including fuel load, ventilation and geometry. Moreover, there is no temperature reduction in the Standard Fire, hence the cooling stage is not considered. 


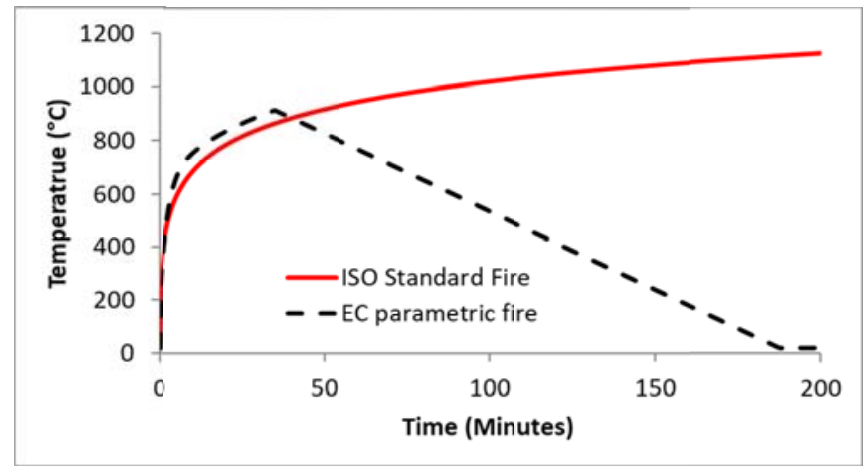

Figure 2: Temperature-time curves

On the other hand, the EC Parametric Fire curve(CEN, 2002) takes into consideration both the heating stage and cooling stage. Therefore the EC Parametric Fire curve is adopted in this study. In the heating stage of the EC Parametric Fire, the gas temperature is defined by:

$$
\theta_{g}=20+1325\left(1-0.324 e^{-0.2 t *}-0.204 e^{-1.7 t *}-0.472 e^{-19 t *}\right)
$$

$t^{*}$ is obtained by the time $\mathrm{t}$ multiplied by a dimensionless parameter $\Gamma$ defined by:

$$
\Gamma=\frac{(O / b)^{2}}{(0.04 / 1160)^{2}}
$$

where $O$ is an opening factor defined by:

$$
O=\frac{A_{v} \sqrt{h_{e q}}}{A_{t}}
$$

$b$ is the thermal absorptivity of the surrounding area of the fire compartment obtained by:

$$
b=\sqrt{\rho c \lambda}
$$

where $A_{v}$ is the total area of vertical openings on the walls, $h_{e q}$ is the average window height on the wall, $A_{t}$ is the total area of the enclosure, $\rho$ is the density, $c$ is the specific heat and $\lambda$ is the thermal conductivity of the boundary of the enclosure.

The cooling stage is generated by:

$$
\begin{aligned}
& t_{\text {max }}^{*} \leq 0.5 h \rightarrow \theta_{g}=\theta_{\text {max }}-625\left(t^{*}-t_{\text {max }}^{*}\right) \\
& 0.5 h<t_{\text {max }}^{*}<2 h \rightarrow \theta_{g}=\theta_{\text {max }}-250\left(3-t_{\text {max }}^{*}\right)\left(t^{*}-t_{\text {max }}^{*}\right) \\
& t_{\text {max }}^{*} \leq 2 h \rightarrow \theta_{g}=\theta_{\text {max }}-250\left(t^{*}-t_{\text {max }}^{*}\right)
\end{aligned}
$$


where maximum gas temperature occurs in the heating stage at $t^{*}{ }_{\max }$ obtained by:

$$
\begin{aligned}
& t_{\text {max }}^{*}=\left(0.2 \times 10^{-3} q_{t, d} / O\right) \Gamma \\
& q_{t, d}=q_{f, d} A_{f} / A_{t}
\end{aligned}
$$

where $q_{t, d}$ is the fire load density, $A_{f}$ is floor area and $A_{t}$ is the total area of the enclosure.

The EC Parametric Fire is influenced by many factors including the fire protection system, degree of ventilation and the fire load. Thus, the fire load density $q_{f, d}$ is defined by:

$$
q_{f, d}=\delta_{q 1} \delta_{q 2} \delta_{n} m q_{f, k}
$$

where $\delta_{q 1}$ is the risk of fire activation, $\delta_{q 2}$ is the type of occupancy, $\delta_{n}$ is the active firefighting measure, $m$ is the combustion factor and $q_{f, k}$ is the characteristic fire load density.

As mentioned above, the EC Parametric Fire expression offers flexibility in considering various fire scenarios. In this study the fire load is taken as $511 \mathrm{MJ} / \mathrm{m}^{2}$, which is obtained from Annex E of Eurocode $1(\mathrm{CEN}, 2002)$ for office buildings. The opening factor is taken as $0.06 \mathrm{~m}^{1 / 2}$ and the thermal inertia of compartments is taken as $1470 \mathrm{Ws}^{0.5} / \mathrm{m}^{2} \mathrm{~K}$. Figure 3 shows the time-temperature curve of the EC Parametric Fire used in this study. With this fire curve, the steel temperature is calculated according to Eurocode 3(CEN, 2005a) for simplicity and the concrete slab temperature is determined by heat transfer analysis. The structural elements' temperatures are shown in Figure 4.

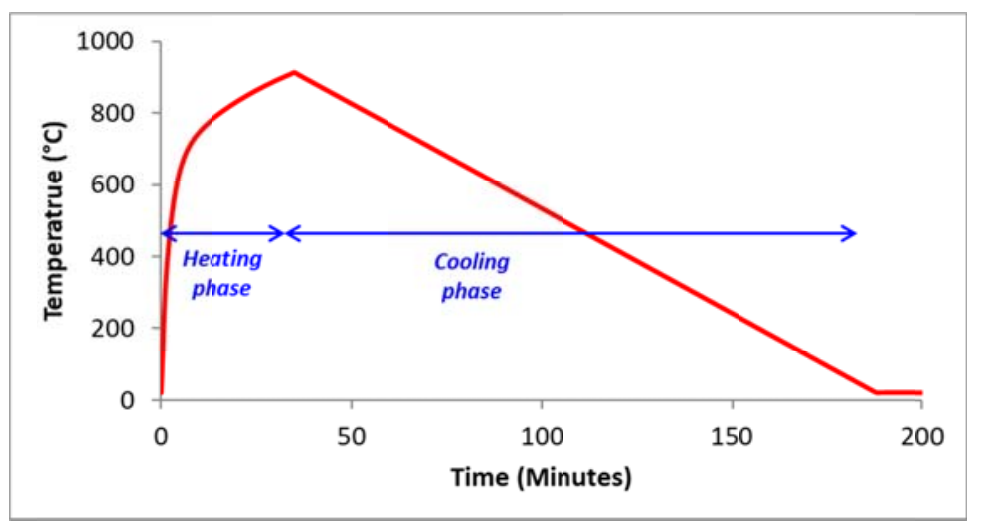

Figure 3: EC Parametric Fire curve 


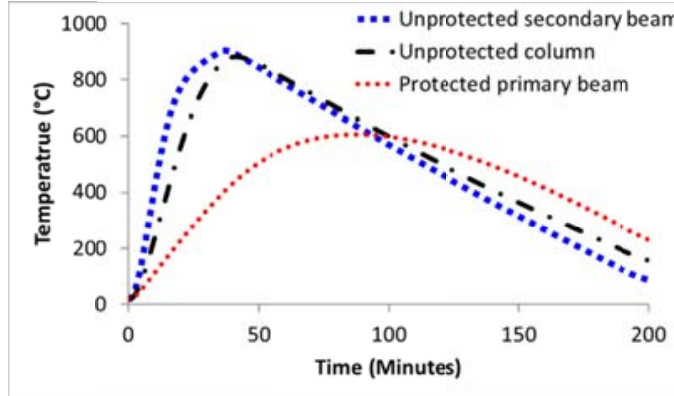

Steel

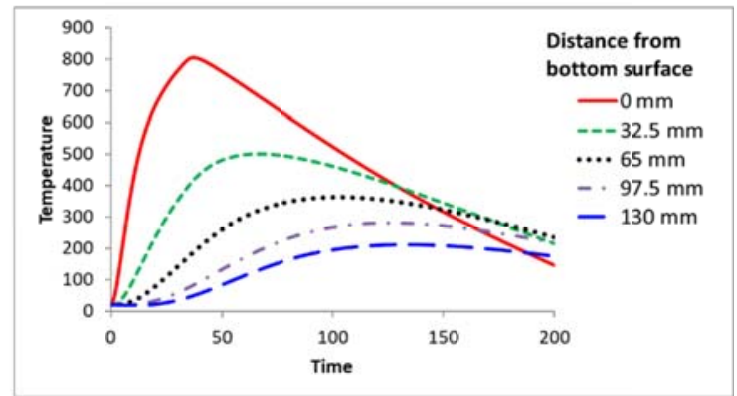

Concrete

Figure 4: Temperature of structural elements exposed to the EC Parametric Fire

This study considers a series of fire scenarios located in the ground floor only. In practice it is common for steel columns to have fire protection. The UK Cardington test (Kirby, 1998), which involved fire testing on a composite steel frame of similar proportions to the subject building here, showed that collapse will not occur when the column is fully protected. However, the fire proofing material can get detached from the steel surface during an extreme event such as an explosion. Therefore, the columns herein are considered to be totally unprotected. It is recognised that this scenario may not be common in practice and represents an extreme case. However, this study focusses on the collapse resistance of the building after buckling of individual columns which is a key driver in the frame collapse. On the other hand, the main (primary) beams are assumed to be protected while the secondary beams are left unprotected to utilise tensile membrane action, an approach commonly adopted in performance-based design (Bailey, 2004). Previous work by Suwondo et al. (2018) shows that heating at the primary beam may result in larger deflection without collapse. Based on this consideration, the primary beams remain protected in the current study.

\section{Numerical model and validation studies}

The commercial finite element software ABAQUS v.6.14 is adopted to model the structure. There are a number of hexahedron, shell and beam elements with different characteristics available in ABAQUS. A simplified 3D model is developed to produce a more realistic estimate of structure behaviour while minimising computational time. Steel beams and columns are discretised using 1-D line elements (ABAQUS library code B31). It should be noted here that 1-D line elements cannot capture local buckling of the elements. Previous studies(Correia \& Rodrigues, 2012; Couto et al., 2015; Yang et al., 2005, 2006b, 2006a) have shown that local buckling can generally be avoided by using semi-compact sections, designated as class 3 in Eurocode 3(CEN, 2005a), with a small value of the parameter $\varepsilon$. Thus, in this study, steel beams and columns are designed using Class 3 sections with the parameter $\varepsilon=0.85 \sqrt{ }(235 / f y)$ instead of $\varepsilon=\sqrt{ }(235 / f y)$ (Couto et al., 2015). 
The connection of the primary-to-secondary beams and the column-to-beams are assumed as pinned and fixed respectively. Therefore, this study does not consider connection failures. The connections are simulated using ABAQUS's joint-rotation connector. The concrete slab is modelled using shell elements (ABAQUS library code S4R) and rebar is defined using the rebar option available in ABAQUS. Shear studs are not modelled directly, instead tie constraints are assigned between the steel beam and slab to represent fully composite action. Following a sensitivity study, a mesh size of $0.5 \mathrm{~m} \times 0.5 \mathrm{~m}$ is adopted for the first-floor slab while a mesh size of $1.0 \mathrm{~m} \times 1.0 \mathrm{~m}$ is implemented for the upper floor slabs to save the computational cost. A maximum mesh size of $0.5 \mathrm{~m}$ is applied for all columns and beams. Figure 5 details the finite element mesh for the analysed building frame.

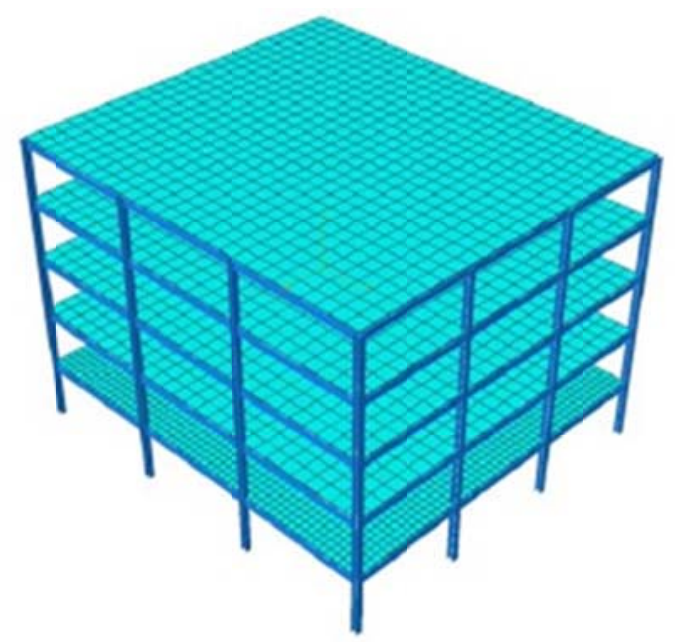

Figure 5: Finite element mesh of the subject building frame

In the material modelling approach, elastic-perfectly plastic steel behaviour was implemented and its temperature-dependent properties are taken as defined by Eurocode 3(CEN, 2005a). Concrete material is specified using a damaged plasticity model available in ABAQUS(Abaqus, 2014), based on the work of Lubliner et al.(1989). The parameters used for concrete damaged plasticity are: dilatation angle $=40^{\circ}$, eccentricity $=0.1$, ratio of equibiaxial compressive yield stress to uniaxial compressive yield stress $f_{b 0} / f_{c 0}=1.16$, ratio of the second stress invariant on the tensile meridian to that on the compressive meridian $K=0.667$ and viscosity parameter $=0$. The tensile strength of concrete is assumed to be $10 \%$ of the compressive strength(Schneider, 1988). Temperaturedependant properties for concrete are adopted as defined by Eurocode 2(CEN, 2004a). It should be noted that the reduction of the compressive strength of the concrete after the heating stage is not considered. The mechanical properties for concrete and steel at elevated temperature are shown in Figure 6. 


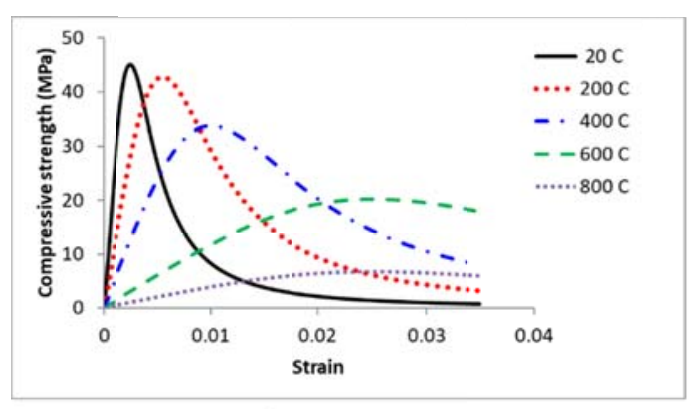

Concrete

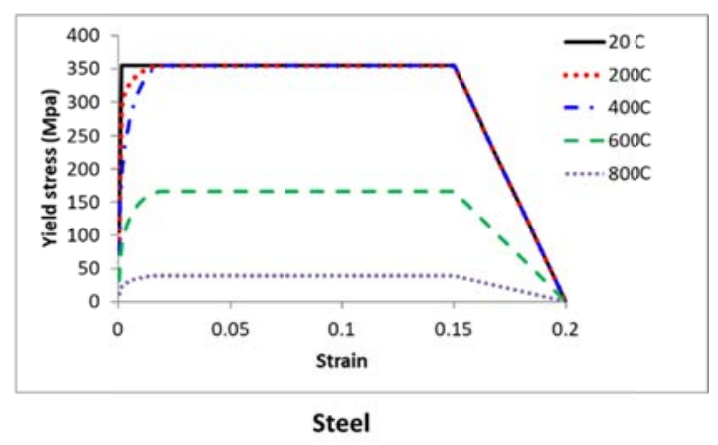

Steel

Figure 6: Elevated temperature stress-strain curves for concrete (left) and steel (right)

A two-step procedure is performed in the analysis. The gravity load (dead plus live load) is firstly applied to the building. Following this a thermal-mechanical analysis of the structure is performed. As discussed in the literature, dynamic effects may occur when a column buckles suddenly. Thus, explicit dynamic analyses are used to capture the dynamic effects during the failure process of the columns and to avoid numerical convergence difficulties. The analysis running time was reduced for computational efficiency. The effect of timescale will be discussed later. In this study, Rayleigh damping is applied with viscous damping of $5 \%$ in the dynamic analysis. The Johnson-Cook damage model(Johnson \& Cook, 1985) was implemented in the steel element to represent possible strain rate effects, the equation of which is:

$$
\varepsilon_{d}=\left[D_{1}+D_{2} \exp \left(D_{3} \sigma^{*}\right)\right]\left[1+D_{4} \ln \varepsilon^{*}\right]\left[1+D_{5} T^{*}\right]
$$

where $\varepsilon_{d}$ is the equivalent plastic strain; $\sigma^{*}$ is a function of stress triaxiality defined as $\sigma^{*}=\sigma m / \bar{\sigma} ; \varepsilon^{*}$ is strain rate; and $T^{*}$ is homogenous temperature. The five constants $D 1-D 5$ are $0.05,3.44,-2.12$, 0.002 , and 0.61 respectively as suggested by Johnson-Cook(1985).

Analysing structures at elevated temperature is a complex and challenging process since it involves many factors that may not be included at ambient temperature such as material and geometric nonlinearity, time-temperature-varying strength, etc. Therefore validation is required to show that the results obtained from the modelling approach capture the relevant mechanics. In this study, benchmark problems originally analysed by Gillie(2009) and progressive collapse analysis by Jiang et al.(2017a) was selected to validate the current modelling approach and to show that the approach captures all the required phenomena at elevated temperature.

\subsection{Analysis of a composite slab subject to fire}

The behaviour of the numerical model of a composite slab in a fire was validated against a benchmark problem originally investigated by Gillie(2009). Figure 7 shows the benchmark model which is the simplified UK Cardington test number 1(Kirby, 1998). The Young's modulus and yield strength of the steel are $210 \mathrm{GPa}$ and $300 \mathrm{MPa}$, respectively while the concrete slab thickness is $130 \mathrm{~mm}$. The 
reinforcement consisted of a grid of $6 \mathrm{~mm}$ diameter bars at $200 \mathrm{~mm}$ centres in each direction and located at the mid-depth of the concrete slab. Symmetry boundary conditions are applied to all external edges. The compressive strength of the concrete is $47 \mathrm{MPa}$, while the yield strength of rebar is taken as $450 \mathrm{MPa}$.

The slab carries a gravity load of $5.48 \mathrm{kN} / \mathrm{m}^{2}$. The shaded area indicated in Figure 7 is subjected to the temperature load. The secondary beam is heated up to $800^{\circ} \mathrm{C}$ while the lower surface of the slab is heated to $600^{\circ} \mathrm{C}$ with a linear gradient of $4.6^{\circ} \mathrm{C} / \mathrm{mm}$. This leads to the upper surface of the slab having a temperature of $0^{\circ} \mathrm{C}$. Following heating, the structure is cooled to ambient temperature.

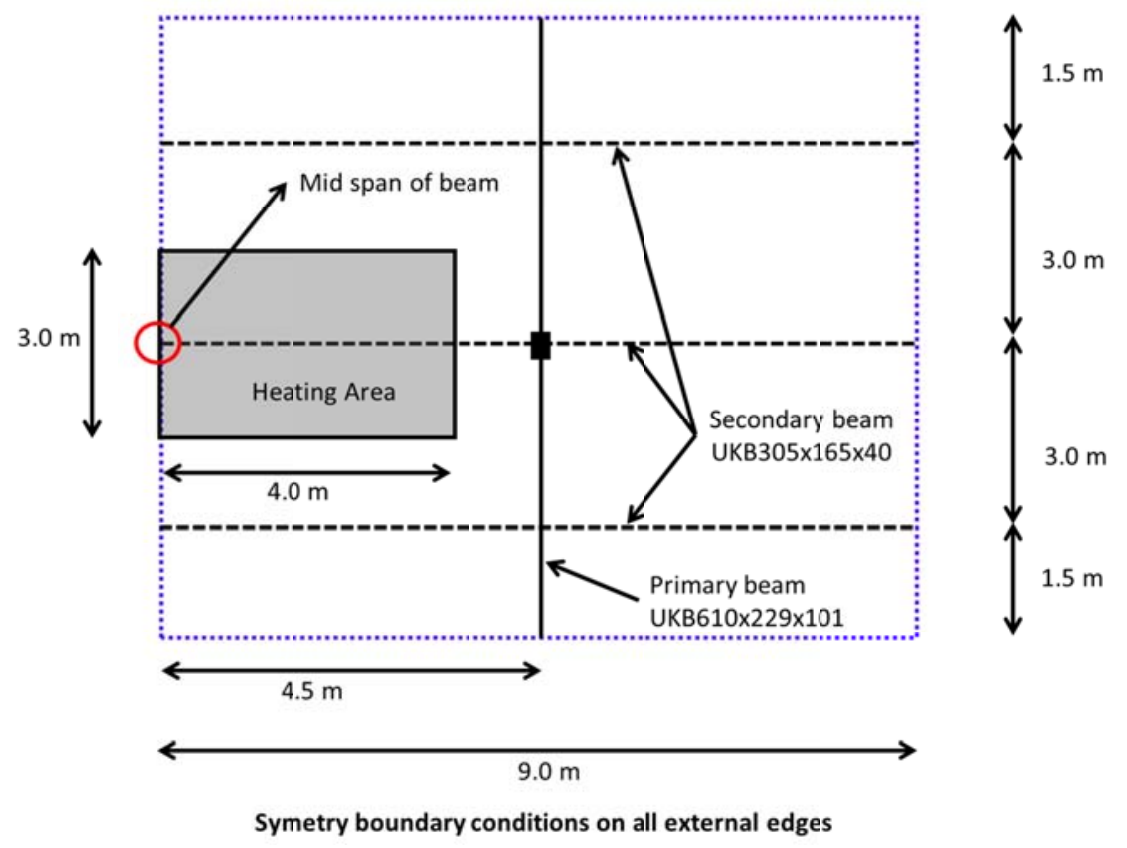

Figure 7: Plan view of the simplified model of the UK Cardington test \#1 by Gillie (2009)

In the finite element method, mesh size is one of the important parameters that may affect the accuracy of the analysis. A fine mesh model increases the accuracy at the expense of computational time. By contrast, a coarser mesh size reduces running time but leads to less accurate results compared to those of the fine mesh. Thus, a mesh sensitivity study is required to obtain the appropriate model used in the numerical analysis. Figure 8 presents the deflection at the mid-span of the beam with different mesh sizes compared to the experimental results(Kirby, 1998) and the model undertaken by Gillie(2009). It shows the general patterns of the deflections are similar for all cases. As expected, the peak deflection happens at the heating stage when the temperature reaches $800^{\circ} \mathrm{C}$. Furthermore, the mesh size of $1.0 \mathrm{~m}$ and $1.5 \mathrm{~m}$ slightly under-predict the displacement at temperature up to $700^{\circ} \mathrm{C}$. On the other hand, the mesh sizes of $0.5 \mathrm{~m}, 0.3 \mathrm{~m}$ and $0.1 \mathrm{~m}$ give reasonable predictions compared to the experimental result. 


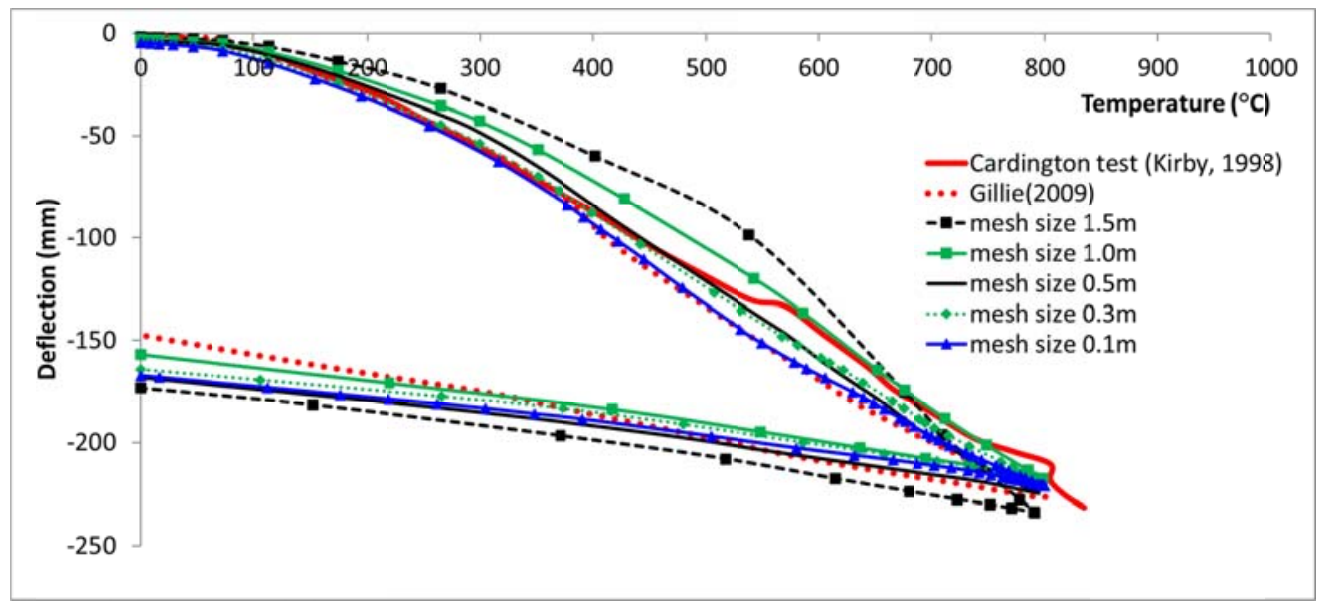

Figure 8: Effect of mesh size on mid-span beam deflection vs. temperature

\subsection{Progressive collapse analysis of a steel moment frame subjected to fire}

Experimental work previously carried out by Jiang et al.(2017a) forms the next case-study. This experiment was also subsequently analysed numerically by Jiang et al.(2017b). These works provided data on the post-buckling of heated columns during the cooling stage and also on the subsequent progressive collapse behaviour of the frame.

Figure 9 shows the test frame. Rectangular hollow sections are adopted for all steel columns and beams. The column and beam sections are $50 \times 30 \times 3 \mathrm{~mm}$ and $60 \times 40 \times 3 \mathrm{~mm}$ respectively. The steel beams and columns are modelled using line elements as previously described. Ten elements are meshed for each column and 20 elements for the beam. At ambient temperature, the steel columns have yield strength of $380 \mathrm{MPa}$ and Young's modulus of $200 \mathrm{GPa}$ while the steel beams have the yield strength of $306 \mathrm{MPa}$ and Young's modulus of $200 \mathrm{GPa}$. A thermal expansion coefficient of $1.4 \times 10^{-5}{ }^{\circ} \mathrm{C}^{-1}$ was used for all steelwork.

Following application of the gravity loads, the column and parts of the adjacent beams indicated by the shaded area in Figure 9a are heated. The temperature variation is shown in Figure 9b. For computational efficiency, the running time of analysis is scaled down from the physical test. Figure 10 presents the results of analysis with different running times. It can be seen that the buckling temperature of the columns is slightly affected by the scaled time. Very good agreement is achieved when a running time of $9 \mathrm{~s}$ (scale 1 -h to $6 \mathrm{~s}$ ) is used with $0.5 \%$ error, as shown in Table 1 . However, the scaled time causes some oscillation in the numerical output. To reduce the oscillation, the time step needs to be increased, which will consequently increase the computational effort. 


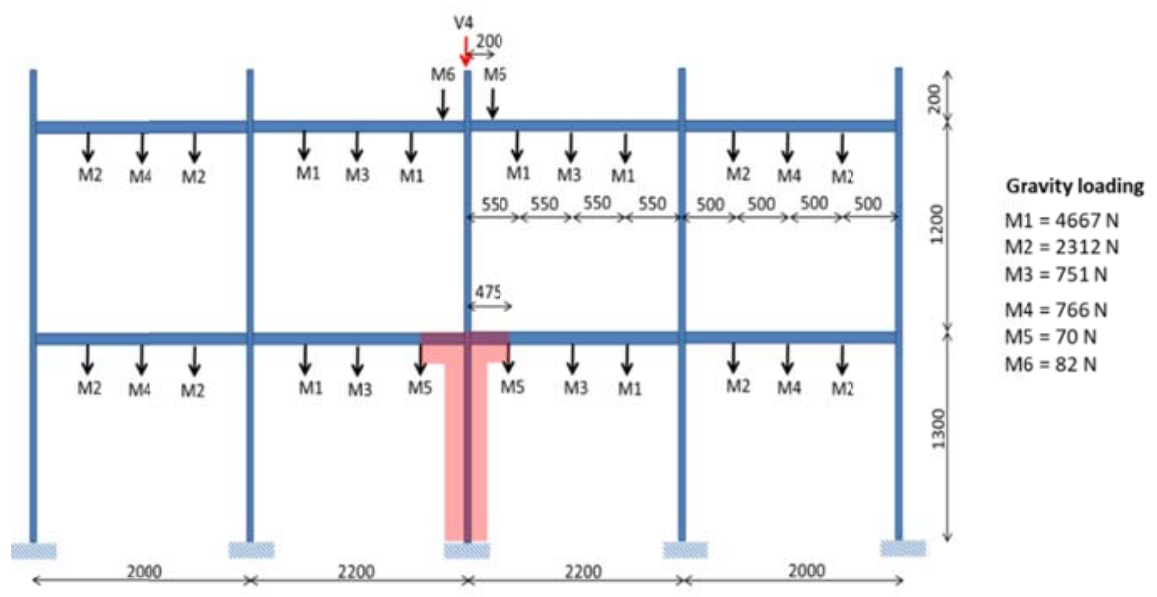

a. The test frame (dimension in $\mathrm{mm}$ )

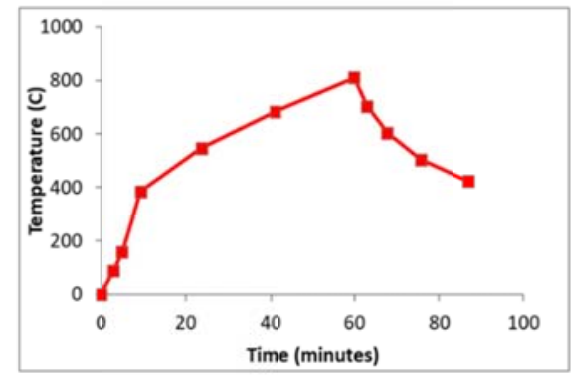

b. Temperature loading

Figure 9: Geometry of the test frame and temperature loading by Jiang et al. (2017a)

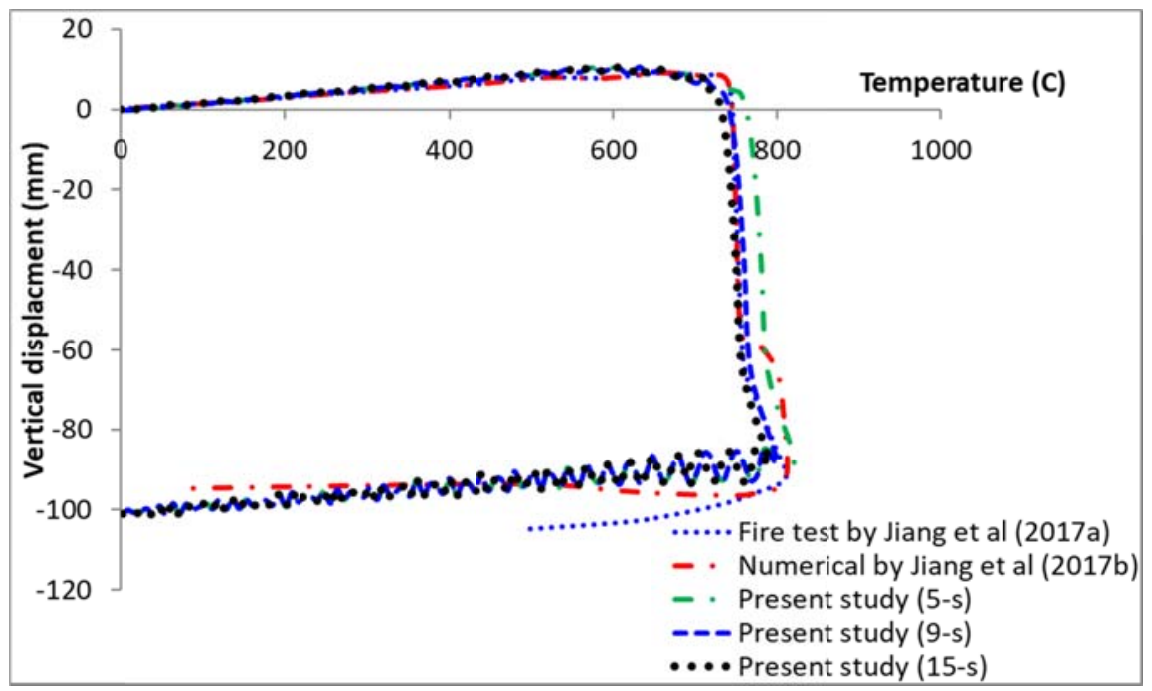


Figure 10: Vertical displacement at the top of column V4 versus temperature - influence of numerical running time

Table 1: Buckling temperature and the percentage error

\begin{tabular}{|c|c|c|}
\hline Time step & $\begin{array}{c}\text { Buckling } \\
\text { temperature }\end{array}$ & Error (\%) \\
\hline Jiang et al. (2017a) & 749 & 0 \\
\hline 5 & 764 & 2.00 \\
\hline 9 & 745 & 0.53 \\
\hline 15 & 740 & 1.20 \\
\hline
\end{tabular}

\section{Robustness analysis of the subject frame under multiple fire scenarios}

This section details the robustness analyses of the 3D composite frame building described in section 2 subject to fire with different sizes of fire compartment, starting from one bay, three bays and lastly the whole ground floor as the fire compartment. This analysis aims to study the effect of fire size and fire location on the collapse resistance of the structure.

\subsection{Fire compartment in one bay}

Three different fire scenarios based on fire locations, interior bay, side bay and corner bay, as shown in Figure 11, are investigated. This analysis is intended to examine specifically the effect of fire location on the robustness of the building under localised fire. In this case, one bay including the columns, beams and slabs is heated.
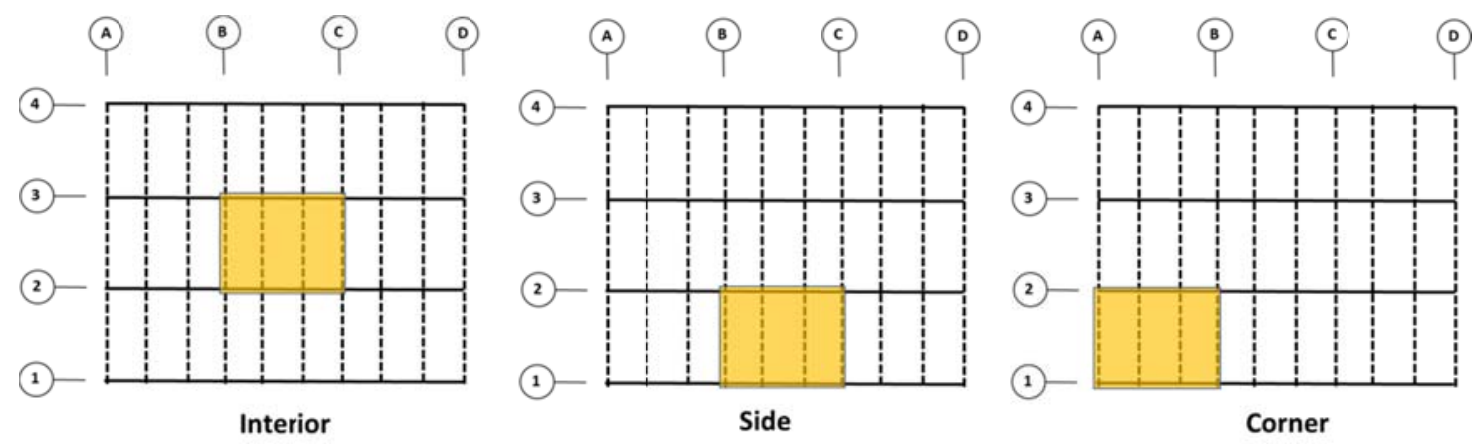

Figure 11: Fire scenarios for one-bay fire compartment

Figure 12 presents the axial displacement and forces of the heated columns and the neighbouring column for the case of fire located in the interior bay. It should be noted that the dashed lines and the 
solid lines represents the heated columns and the neighbouring columns (cool), respectively. In addition, the name of each column is based on the grid line as shown in Figure 11. It can be seen that the top of the heated column initially expands upward owing to thermal expansion with increasing temperature. Hence, the increase of axial forces at the heated column occurs due to the restraint caused by the neighbouring elements. This results in reduction of the axial forces at the neighbouring columns.

When the heated columns start to buckle, the vertical displacement of the columns suddenly decreases as temperature increases. During this phase, the heated columns lose their load-bearing capacity. Following this, the loads previously resisted by the heated column are transferred to the neighbouring columns. Hence, the axial forces at the neighbouring columns gradually increase, as shown in Figure 12. However, the vertical displacement of the neighbouring columns is relatively little as they do not buckle. During the cooling stage, the axial displacements of the heated columns move downward rather than return to the original shape. This is because large tension occurs at the heated columns as a result of thermal contraction. Accordingly, the adjacent columns will sustain extra loads during the cooling stage. This shows that the cooling period may be more critical compared to the heating period.
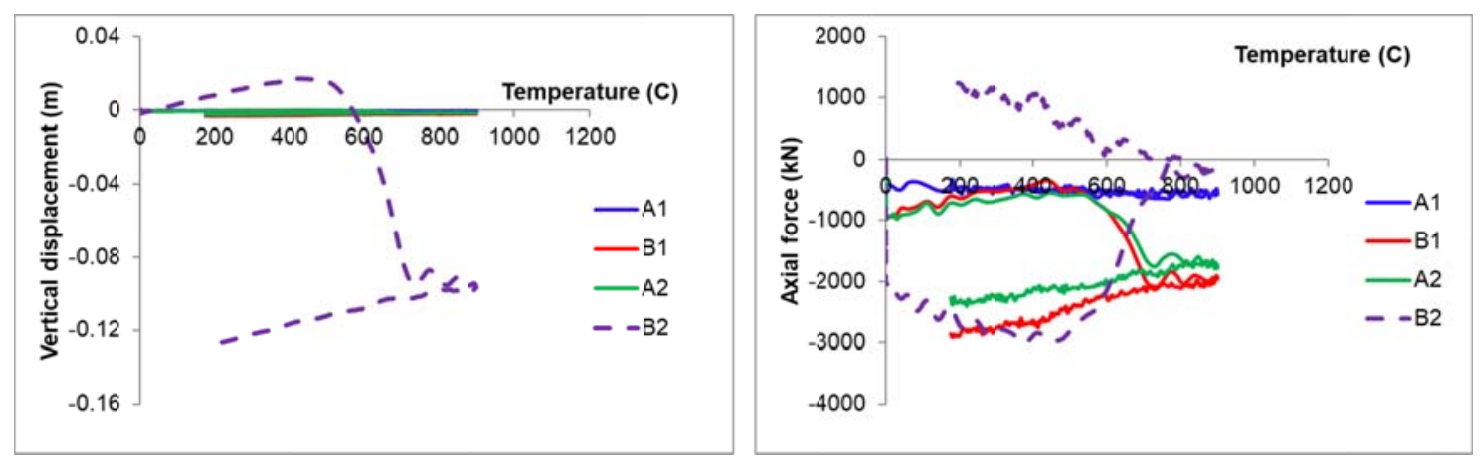

Figure 12: Axial displacement and forces for the ground floor columns at ground floor (interior-bay fire scenario)

Figure 13 presents the variation of the axial displacement and axial forces of the columns when the fire is located at the side-bay. It can be noticed that the failure of the heated columns (B1 and B2) occurs at different temperature and time. Heated column B2 buckles earlier than the heated column B1 because B2 has a higher load ratio compared to B1. The failure sequence can also be observed based on the buckling resistance of the column. Once column B2 buckles, the axial force of the neighbouring columns increases gradually then there is an increase in axial force when buckling of the heated column B1 occurs. 

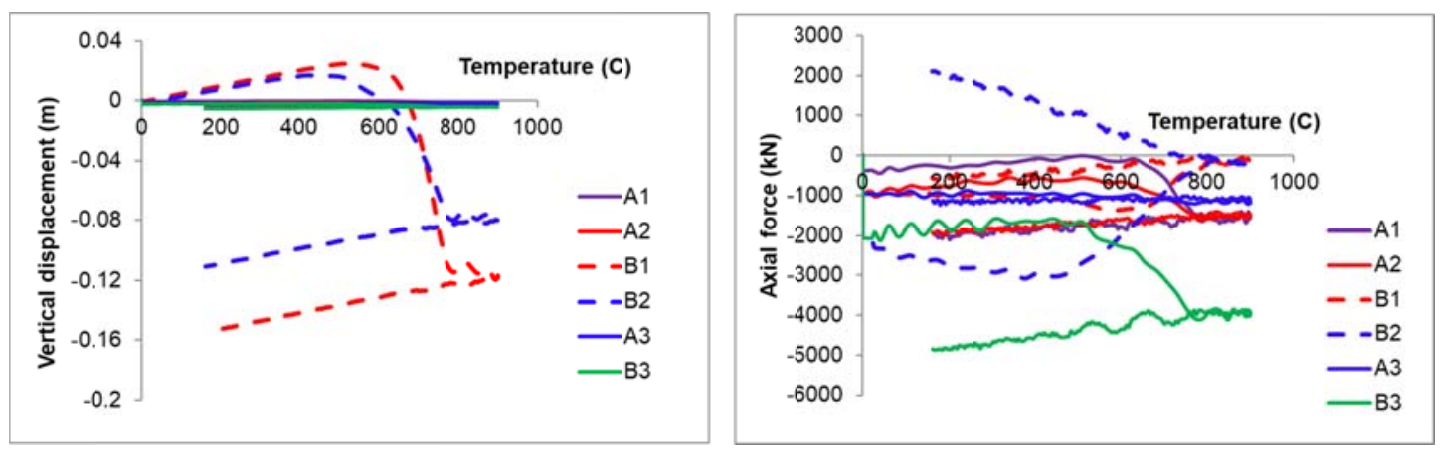

Figure 13: Vertical displacement and axial forces of the columns at ground floor (side-bay fire scenario)

Similar behaviour can be noticed for the case of a corner-bay fire scenario. Figure 14 shows that the heated column B2 is first to buckle followed by the heated side columns (A2 and B1) and the heated corner column A1. Interestingly, progressive or runaway failure occurs at the heated corner column A1 although it has a relatively lower load ratio. This runaway failure may be due to the fact that there is no redistribution of loads since the adjacent columns have already buckled. However, the building can re-stabilise just after the runaway failure owing to the capability of the whole building to carry the catenary force developed by the floor beam.
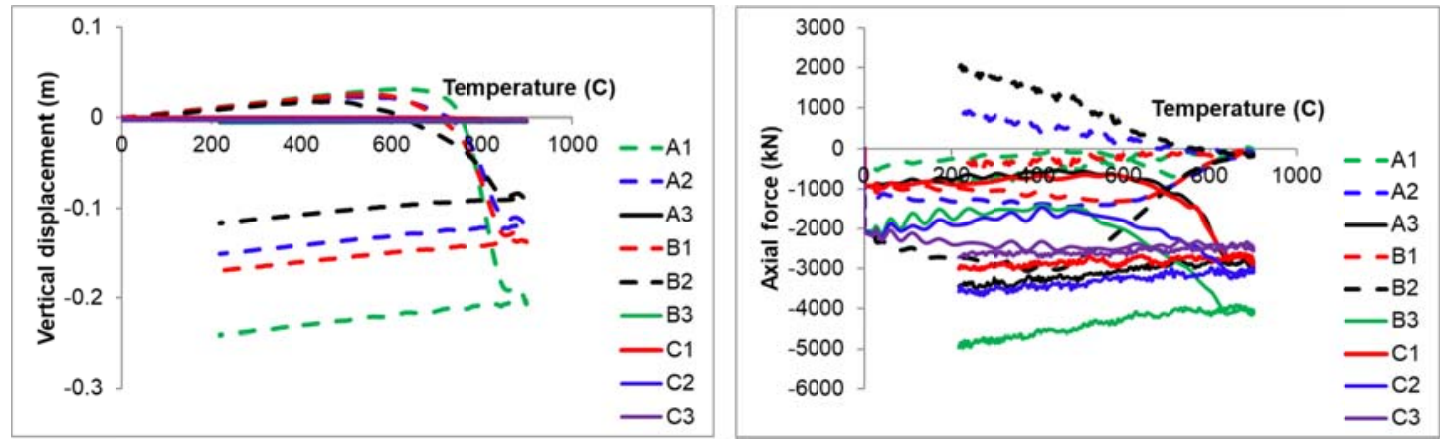

Figure 14: Axial displacement and forces of the columns at ground floor (corner-bay fire scenario)

The analyses show the load redistribution path in the structural elements when the building is subjected fire located in one bay only. The loads formerly resisted by the heated column are 
redistributed to the surrounding columns. This can be confirmed by the evolution of axial force in the heated columns and the neighbouring columns with increasing temperature. The stress distribution at the composite slab, as shown in Figure 15, demonstrates that the load distribution is mainly affected by the protected steel beam. The buckling temperature at the heated column is influenced by the load ratio of the column, as shown in Table 2. Furthermore, it can be observed that no collapse occurs when the building is subjected to fire located in one bay. This may be the result of the columns having a relatively small load ratio so that the loads sustained by the failure of a column can be shifted to the neighbouring columns without triggering buckling or progressive collapse.

Table 2: Buckling temperature at the heated columns

\begin{tabular}{|c|c|c|}
\hline \multicolumn{3}{|c|}{ Interior-bay scenario } \\
\hline Heated column & Load ratio & $\begin{array}{c}\text { Column buckling } \\
\text { temperature }\left({ }^{\circ} \mathrm{C}\right)\end{array}$ \\
\hline B2 & 0.3 & 510 \\
\hline \multicolumn{3}{|c|}{ Side-bay scenario } \\
\hline Heated column & Load ratio & $\begin{array}{c}\text { Column buckling } \\
\text { temperature }\left({ }^{\circ} \mathrm{C}\right)\end{array}$ \\
\hline B1 & 0.14 & 590 \\
\hline B2 & 0.3 & 517 \\
\hline Heated column & Load ratio & $\begin{array}{c}\text { Column buckling } \\
\text { temperature }\left({ }^{\circ} \mathrm{C}\right)\end{array}$ \\
\hline A1 & 0.05 & 680 \\
\hline A2 & 0.13 & 600 \\
\hline B1 & 0.14 & 600 \\
\hline B2 & 0.3 & 510 \\
\hline
\end{tabular}




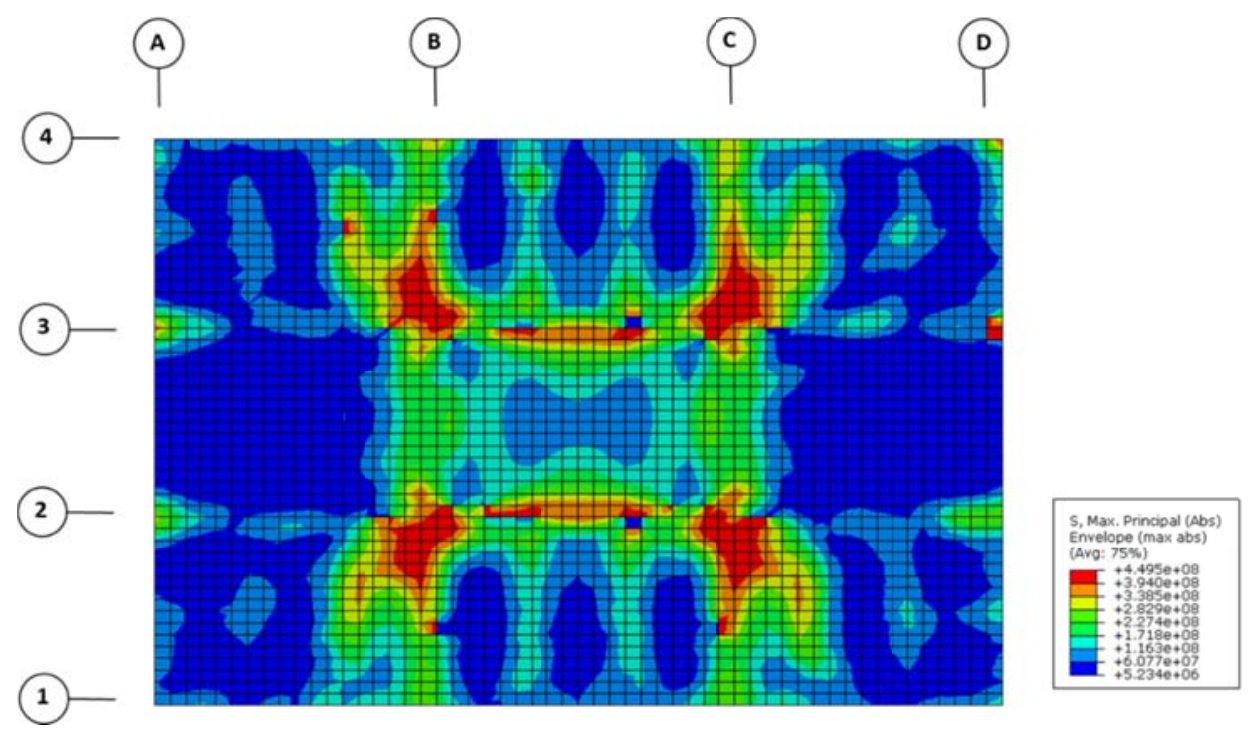

Figure 15: Maximum principal stress of the rebar at maximum temperature $\left(900^{\circ} \mathrm{C}\right)$ (internal bay fire scenario)

\subsection{Fire compartment in three bays}

This section presents the robustness analysis of the building subjected to three-bay compartment fires. Two different locations i.e. three inside-bay and three outside-bay, as shown in Figure 16, are considered.
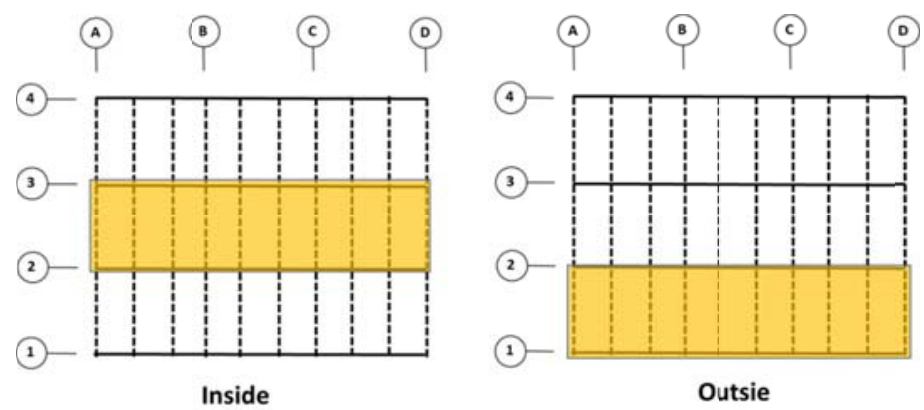

Figure 16: Fire scenarios for a three-bay fire compartment

Figure 17 shows vertical displacement and axial forces of the heated columns and neighbouring columns for the case of a three inside-bay fire. The internal columns with higher load ratio buckle earlier compared to the edge columns, however the structure sustains local damage without collapse. This is expected since the edge columns have very low load ratios, hence they can safely support extra load resulting from buckling of the heated columns. 

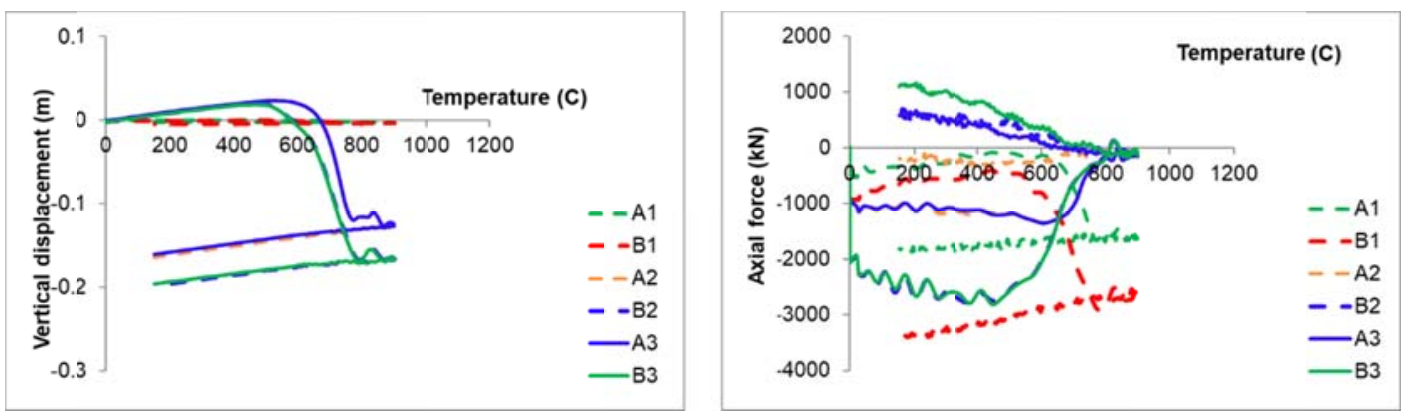

Figure 17: Axial displacement and forces of the columns at ground floor (three inside-bay fire scenario)

By contrast, the three outside-bay fire scenario leads to the global collapse of the building. When the runaway failure occurs, as shown in Figure 18, the building fails to maintain its stability. It can also be noticed that the collapse occurs during the cooling stage. Axial tension force in the heated columns during the cooling stage causes additional vertical loads as well as lateral forces to the adjacent column, causing total collapse of the building. Figure 19 illustrates the collapse mode of the building. These analyses demonstrate that fire safety design should include consideration of different fire scenarios.
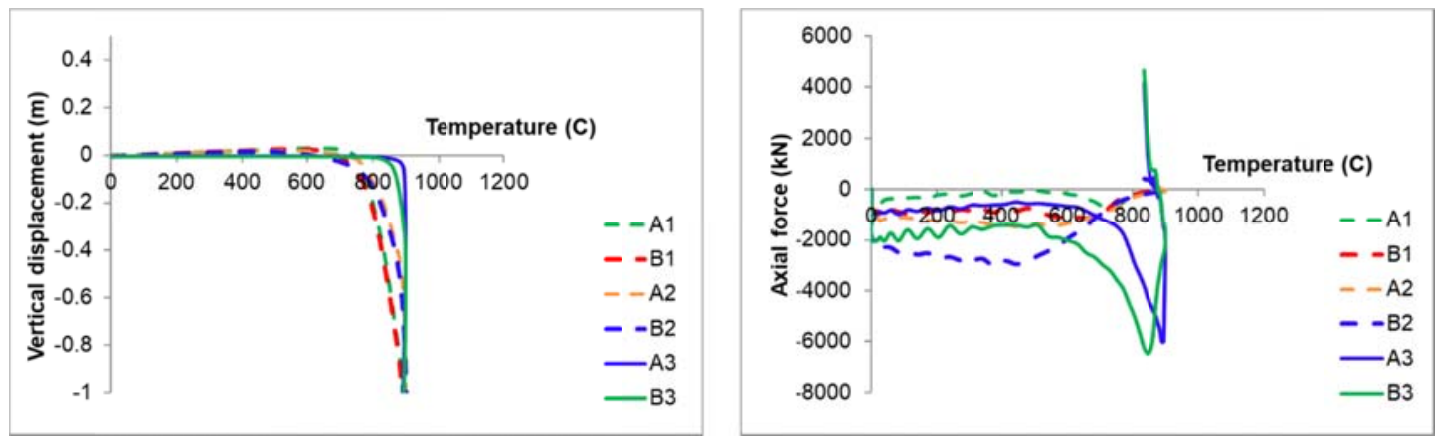

Figure 18: Axial displacement and forces of columns at ground floor (three outside-bay fire scenario) 


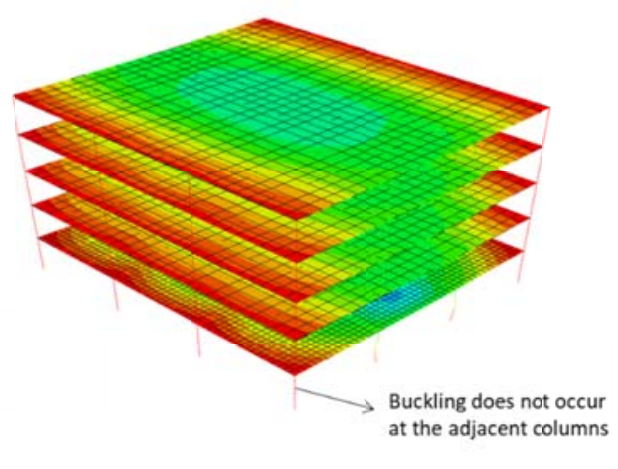

a. Three-inside bay

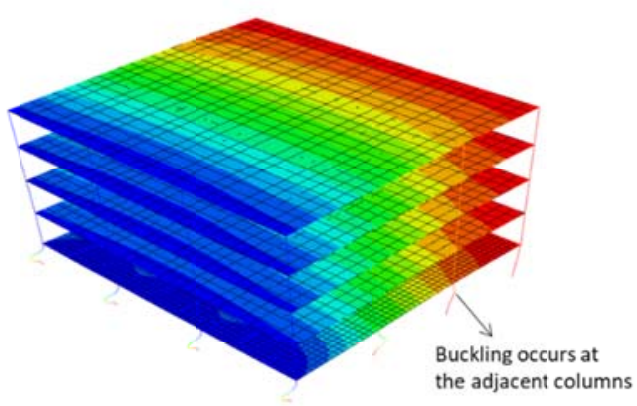

b. Three-outside bay

Figure 19: Collapse mode of the building for the three-bay scenarios

\subsection{Fire compartment in the whole ground floor}

This study has so far focused on the behaviour of the building subject to localised fires. In this case, the building is exposed to fire on the entire ground floor including the beams, columns and composite slab. As expected, the building collapses earlier compared to the previous fire scenarios. This is because there is no alternative load path as all the columns experience buckling, as shown in Figure 20.
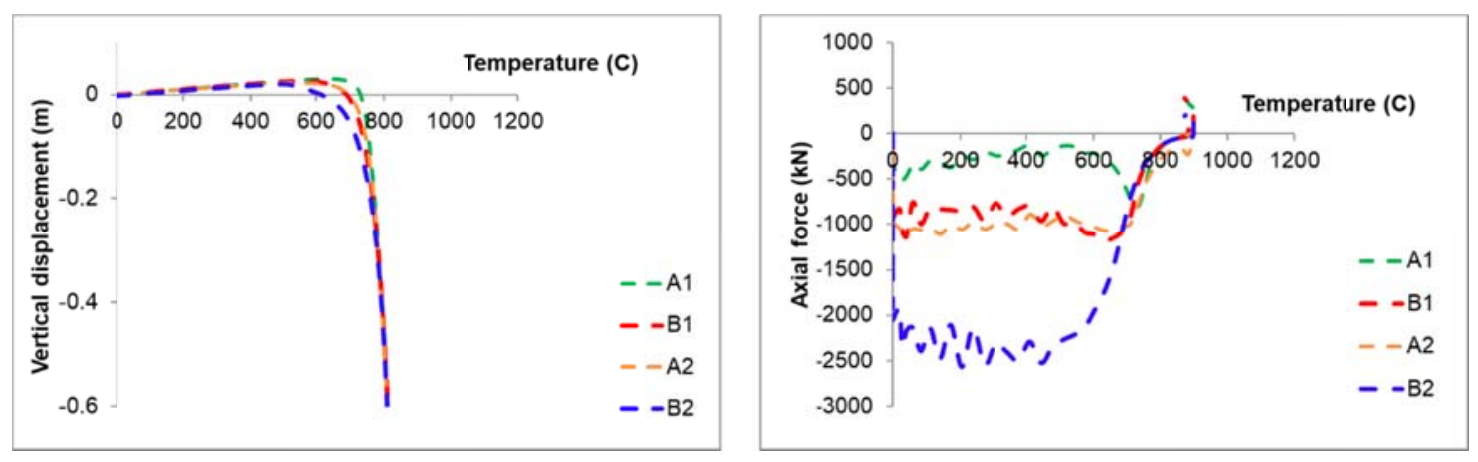

Figure 20: Axial displacement and forces of the heated columns (whole ground floor fire scenario)

In addition, two separate analyses have been performed to investigate the critical elements that could have influenced the collapse resistance of the building. First, the slab and the beams at the ground floor are exposed to fire. Secondly, only the columns on the ground floor are exposed to fire. 
Figure 21 shows mid-span deflection of the composite slab. It can be observed that initially, the deflection increases as a result of continuous heating. During the cooling stage, the deflection keeps increasing since the temperature at the protected beam and the concrete slab is relatively high, as shown in Figure 4. The large deflection that occurs in the composite slab does not cause the collapse of the building and stability is maintained.

By contrast, heating all the columns at the ground floor results in collapse of the building even though the composite slab remains cool. Figure 22 shows the comparison of axial displacement between heating all structural elements and heating only the columns on the ground floor. It is observed that both cases have a similar pattern of collapse. This demonstrates that the collapse of the structure is mainly caused by the buckling of the column.

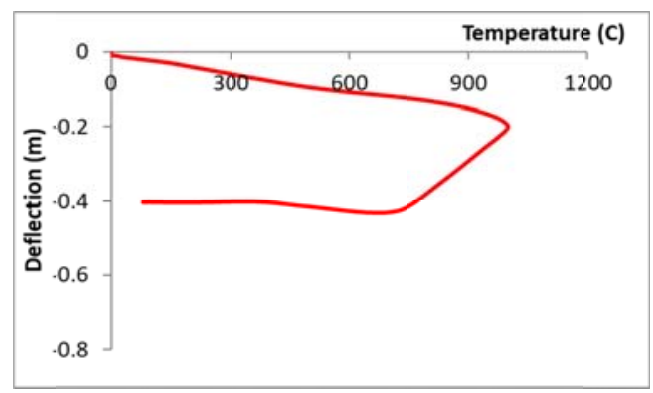

Figure 21: Slab mid-span deflection for the case of the slab and the beams exposed to fire

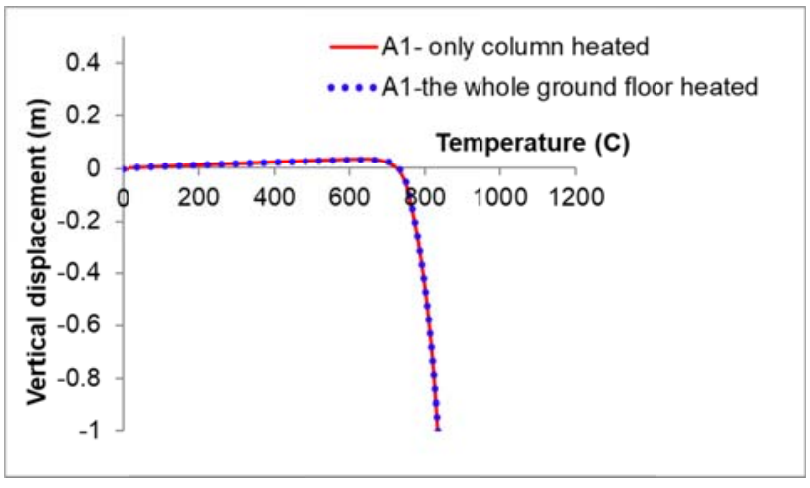

Figure 22: Comparison of axial displacement between heating all structural elements and heating only the columns

\section{Conclusions}

This paper has presented a numerical investigation of the robustness of a composite steel frame building subjected to multiple fire scenarios. Simplified 3D models have been developed to simulate 
the progressive failure of the building in a fire. The following conclusions can be drawn based on this study:

- The 3D model approach used here provides a realistic estimate of building behaviour in fire against progressive collapse. The model is able to capture the load redistribution along two horizontal directions after the failure of the columns.

- The subject building is still able to resist progressive collapse when fire is located at one bay only. The loads formerly sustained by failed members are transferred safely to adjacent elements and the spread of local failure leading to collapse can be prevented.

- The cooling stage can be more dangerous than the heating stage as the columns expand downward, resulting in further damage during this phase. In other words, the standard fire curve should not be relied upon to assess the robustness of the building in a fire. The case of the three-bay fire scenario confirms that global collapse could occur during the cooling period.

- Total collapse occurs when fire is located in the edge three-bay case due to catenary action of the beam and associated lateral forces on the columns. This shows that the fire compartment at the edge bay is more critical than the internal bay.

- This study demonstrates that different fire scenarios cause different collapse modes, which has consequences for design. Thus, the designer should detail specific fire containment to avoid structural collapse in a fire situation.

- No structural collapse occurs when the composite slab only is exposed to fire. This is in line with the experimental observations of the UK Cardington test. This demonstrates that the heated composite slab has less influence on the robustness of the building in a fire.

- In contrast, structural collapse occurs when the columns are heated even though the composite slab remains cool. This shows that the collapse of the building is primarily caused by column buckling.

\section{Acknowledgements}

The authors acknowledge the support of the Indonesia Endowment Fund for Education (LPDP) in funding this $\mathrm{PhD}$ research. Similarly, the support provided by the University of Manchester's Department of Mechanical, Aerospace and Civil Engineering is gratefully acknowledged.

\section{References}

Abaqus. (2014). ABAQUS/Standard analysis user's manual v6.13. SIMULIA.

Agarwal, A., \& Varma, A. H. (2014). Fire Induced Progressive Collapse of Steel Building Structures: 
The Role of Interior Gravity Columns. Engineering Structures, 58, 129-140.

https://doi.org/10.1016/j.engstruct.2013.09.020

Bailey, C. G. (2004). Membrane action of slab/beam composite floor systems in fire. Engineering

Structures, 26(12), 1691-1703. https://doi.org/10.1016/j.engstruct.2004.06.006

BS EN. (1990). BS5950 Part 8: Code of Practice for Fire Resistant Design. British Standard Institute, London, $U K$.

BSI. (2014). ISO 834-10:2014 Fire resistance test-elements of building construction. Specific requirements to determine the contribution of applied fire protection materials to structural steel elements.

CEN. (2002). Eurocode 1: Actions on structures. Part 1-2: General actions. Actions on structures exposed to fire. British Standard Institute, London, UK.

CEN. (2004a). Eurocode 2: Design of concrete structures - Part 1-2 General rules - Structural fire design. British Standard Institute, London, UK.

CEN. (2004b). Eurocode 8 - Design of structures for earthquake resistance -Part 1: General rules, seismic actions and rules for building. British Standard Institute, London, UK.

CEN. (2005a). Eurocode 3 : Design of steel structures Part 1-2: General rules - Structural fire design. British Standard Institute, London, UK.

CEN. (2005b). Eurocode 4: Design of composite steel and concrete structures Part 1-2: General rules : Structural fire design. British Standard Institute, London, UK.

Correia, A. J. P. M., \& Rodrigues, J. P. C. (2012). Fire resistance of steel columns with restrained thermal elongation. Fire Safety Journal, 50, 1-11. https://doi.org/10.1016/j.firesaf.2011.12.010

Couto, C., Vila Real, P., Lopes, N., \& Zhao, B. (2015). Resistance of steel cross-sections with local buckling at elevated temperatures. Journal of Constructional Steel Research, 109, 101-114. https://doi.org/10.1016/j.jcsr.2015.03.005

Gillie, M., Usmani, A. S., \& Rotter, J. M. (2001). A structural analysis of the first Cardington test. Journal of Constructional Steel Research, 57(6), 581-601. https://doi.org/10.1016/S0143974X(01)00004-9

Gillie, Martin. (2009). Analysis of heated structures: Nature and modelling benchmarks. Fire Safety Journal, 44(5), 673-680. https://doi.org/10.1016/j.firesaf.2009.01.003

Jiang, B., Li, G.-Q., Li, L., \& Izzuddin, B. a. (2017a). Experimental Studies on Progressive Collapse 
Resistance of Steel Moment Frames under Localized Furnace Loading. Journal of Structural Engineering, 144(2), 1-10. https://doi.org/10.1061/(ASCE)ST.1943-541X.0001947

Jiang, B., Li, G. Q., Li, L., \& Izzuddin, B. a. (2017b). Simulations on progressive collapse resistance of steel moment frames under localized fire. Journal of Constructional Steel Research, 138, 380-388. https://doi.org/10.1016/j.jcsr.2017.05.018

Jiang, J., \& Li, G.-Q. (2017a). Disproportionate collapse of 3D steel-framed structures exposed to various compartment fires. Journal of Constructional Steel Research, 138, 594-607. https://doi.org/https://doi.org/10.1016/j.jcsr.2017.08.007

Jiang, J., \& Li, G. (2017b). Progressive collapse analysis of 3D steel frames with concrete slabs exposed to localized fire. Engineering Structures, 149, 21-34. https://doi.org/10.1016/j.engstruct.2016.07.041

Johnson, G. R., \& Cook, W. H. (1985). Fracture characteristics of three metals subjected to various strains, strain rates, temperatures and pressures. Engineering Fracture Mechanics, 21(1), 31-48. https://doi.org/10.1016/0013-7944(85)90052-9

Kirby, B. R. (1998). The behaviour of multi-storey steel frame building in fire - Technical Report. British Steel.

Lubliner, J., Oliver, J., Oller, S., \& Oñate, E. (1989). A plastic-damage model for concrete. International Journal of Solids and Structures, 25(3), 299-326. https://doi.org/10.1016/00207683(89)90050-4

Porcari, G. L. F., Zalok, E., \& Mekky, W. (2015). Fire induced progressive collapse of steel building structures: A review of the mechanisms. Engineering Structures, 82, 261-267. https://doi.org/10.1016/j.engstruct.2014.09.011

Schneider, U. (1988). Concrete at High Temperatures - - A General Review*. Fire Safety Journal, 13, $55-68$.

Sun, R., Huang, Z., \& Burgess, I. W. (2012). Progressive collapse analysis of steel structures under fire conditions. Engineering Structures, 34, 400-413. https://doi.org/10.1016/j.engstruct.2011.10.009

Suwondo, R., Cunningham, L., Gillie, M., \& Bailey, C. (2018). Improving the performance of composite floors subjected to post-earthquake fire. Fire Safety Journal, 102, 18-26. https://doi.org/10.1016/J.FIRESAF.2018.10.004

Suwondo, R., Cunningham, L., Gillie, M., \& Bailey, C. (2019). Progressive collapse analysis of 
composite steel frames subject to fire following earthquake. Fire Safety Journal, 103(December 2018), 49-58. https://doi.org/10.1016/j.firesaf.2018.12.007

Wang, W.-Y., \& Li, G.-Q. (2009). Behavior of steel columns in a fire with partial damage to fire protection. Journal of Constructional Steel Research, 65(6), 1392-1400.

https://doi.org/10.1016/j.jcsr.2009.01.004

Yang, K. C., Chen, S. J., Lin, C. C., \& Lee, H. H. (2005). Experimental study on local buckling of fire-resisting steel columns under fire load. Journal of Constructional Steel Research, 61(4), 553-565. https://doi.org/10.1016/j.jcsr.2004.07.001

Yang, K. C., Lee, H. H., \& Chan, O. (2006a). Experimental study of fire-resistant steel H-columns at elevated temperature. Journal of Constructional Steel Research, 62(6), 544-553.

https://doi.org/10.1016/j.jcsr.2005.09.008

Yang, K. C., Lee, H. H., \& Chan, O. (2006b). Performance of steel H columns loaded under uniform temperature. Journal of Constructional Steel Research, 62(3), 262-270.

https://doi.org/10.1016/j.jcsr.2005.07.001 